University of Nebraska - Lincoln

DigitalCommons@University of Nebraska - Lincoln

Faculty Publications, Department of Psychology

Psychology, Department of

$11-1-1988$

\title{
The Relations of Pubertal Status to Intrapersonal Changes in Young Adolescents
}

Lorah D. Dorn

Pennsylvania State University

Lisa J. Crockett

University of Nebraska-Lincoln, ecrockett1@unl.edu

Anne C. Petersen

Pennsylvania State University, annepete@umich.edu

Follow this and additional works at: https://digitalcommons.unl.edu/psychfacpub

Part of the Psychiatry and Psychology Commons

Dorn, Lorah D.; Crockett, Lisa J.; and Petersen, Anne C., "The Relations of Pubertal Status to Intrapersonal Changes in Young Adolescents" (1988). Faculty Publications, Department of Psychology. 228.

https://digitalcommons.unl.edu/psychfacpub/228

This Article is brought to you for free and open access by the Psychology, Department of at DigitalCommons@University of Nebraska - Lincoln. It has been accepted for inclusion in Faculty Publications, Department of Psychology by an authorized administrator of DigitalCommons@University of Nebraska - Lincoln. 


\title{
The Relations of Pubertal Status to Intrapersonal Changes in Young Adolescents
}

\author{
Lorah D. Dorn \\ Lisa J. Crockett \\ Anne C. Petersen \\ The Pennsylvania State University
}

\begin{abstract}
The purpose of this study was to investigate the relations between pubertal development and adolescents' perceptions of their physical and emotional states. Two research questions were posed: (a) What are the effects of pubertal status upon satisfaction with appearance and mood states of the adolescent; and, (b) What are the patterns of those pubertal effects in sixth, seventh, and eighth grades? A nonclinical group of adolescents $(\mathrm{N}=253)$ was selected from two cohorts and was followed from sixth through eighth grade. Multiple measures were used to assess satisfaction with appearance and mood states. Significant multivariate findings were limited to seventh and eighth grades. For satisfaction with appearance in girls, there were significant multivariate effects for pubertal status in both grades with the salient variable being satisfaction with weight. Girls who were more physically mature reported being less satisfied with their weight. For moods in seventh grade boys, the multivariate effect was significant for pubertal status with the salient variables being Impulse Control and Emotional Tone. Pubertal boys rated themselves higher, that is better on Impulse Control and Emotional Tone. Other significant univariate effects and polynomial trends are also discussed.
\end{abstract}

Early adolescence is a developmental period in which multiple and often simultaneous changes occur within the individual and in several social contexts important to young adolescents (e.g., Hamburg, 1974; Petersen, 1987). Perhaps the most dramatic changes

The research reported in this paper was supported by grant MH 30252138142 from the National Institute of Mental Health to A.C. Petersen. Contributions by the first author were made, in part, through support from the Department of Health and Human Services, National Research Service Award \#I-F31-NR05965 from the National Center for Nursing Research. 
evident to adolescents, as well as to those around them, are the physical changes that occur as a part of the pubertal process. During puberty, the transition is made from having the physical appearance of a child to appearing as an adult (Petersen \& Taylor, 1980; Tanner, 1962). Rapid increases in height and weight occur; genitalia develop; axillary, pubic, and body hair appear; in boys, the voice deepens and facial hair begins to grow; and in girls breasts and the menstrual cycle develop. Hormone levels also increase rapidly across puberty in both boys and girls. Some of the sex steroids increase by as much as 18 fold in boys and eight fold in girls (Nottelmann et al., 1987a). Many of the external biological changes occur rapidly and require adolescents to integrate these new physical changes, together with the feelings accompanying these changes, into their self-concepts (e.g., Blyth, Simmons, \& Zakin, 1985;Petersen \& Taylor, 1980).

In much of the adolescent literature, it has been assumed that puberty is a major force affecting adolescent behavior (Petersen \& Spiga, 1982). Adolescence has been described as a period of "storm and stress" (Hall, 1904) in which maintenance of equilibrium is abnormal (Freud, 1958). Psychoanalytic theory has attributed adolescent behavioral changes to an increase in the sexual drive (Blos, 1962; Freud, 1953) resulting from the hormonal surge during puberty (Kestenberg, 1967a, 1967b, 1968). Most of this literature has cited negative aspects of behavior or development in adolescence. Conclusions, however, have primarily been drawn from anecdotal reports, observations of a small number of adolescents, or studies of deviant or emotionally disturbed populations. Strong empirical evidence supporting or refuting the role of puberty in adolescent behavior is generally lacking.

Effects of pubertal development have been found in several interpersonal domains, notably family relations (e.g., Hill, Holmbeck, Marlow, Green, \& Lynch, 1985; Papini \& Sebby, 1987, 1988; Steinberg, 1987; Steinberg \& Hill, 1978) and heterosexual behavior (e.g., Billy \& Udry, 1983; Morris, Mallin, \& Udry, 1982). Few empirical studies, however, have addressed the relations of pubertal development to self-perceptions and mood states despite the theoretical literature suggesting such relationships. This study focuses directly on the intrapersonal dimension, specifically on adolescents' feelings about their appearance and their moods. Importantly. the research was conducted with a nonclinical sample of young adolescents.

Apart from the psychoanalytic literature linking puberty to emotional status, several studies have linked hormone levels to behaviors and feelings in adults and adolescents. For example, hormones have direct effects on behavior (Nyborg, 1983) and in adults, hormones are related to stress (Gold et al., 1986a, 1986b; Parker, Levin, \& Lifrak, 1985; Rose, 1980), depression (Tolis \& Stefanis, 1983), other affective disturbances (see Anisman and Lapierre, 1982 for a review), and anorexia nervosa (Gold et al., 1986a, 1986b). In adolescents, hormones are related to aggressive behavior in boys (Olweus, Mattsson, Schalling, \& Low, 1980; Susman, et al., 1987a). More recently, hormones were found to be related to aggressive behaviors in girls when observational data were used (Inoff-Germain, et al., 1988).

Other studies have shown the importance of examining hormones in conjunction with other measures. For example, in girls, hormone status and the interaction between estradiol and pubertal status appeared to be related to depressive affect (Brooks-Gunn 
$\&$ Warren, 1987a). Further, in both boys and girls, specific hormone profiles were related to more adjustment problems (Nottelmann, Susman, Inoff-Germain, Cutler, \& Chrousos, 1987b). However, hormone correlations were dependent upon other markers of development as well (Nottelmann, Susman, Inoff-Germain, \& Chrousos, in press). (For a review see Nottelmann, et al., in press; Susman, Nottelmann, Inoff-Germain, Dorn, \& Chrousos, 1987b.)

In addition, the physical changes of puberty are likely to influence adolescents' self-perceptions and body-image; these changes in self-perceptions may in turn influence adolescents' moods (e.g., Petersen \& Taylor, 1980). Studies finding a relationship between indices of pubertal change and psychosocial variables generally have focused upon adolescents experiencing early or late pubertal development (Blyth, Hill, \& Smith, 1981; Faust, 1983; Jones \& Bayley, 1950; Jones \& Mussen, 1958; Petersen \& Crockett, 1985; Simmons, Blyth \& McKinney, 1983; Susman et al., 1985). Generally, these studies have shown mixed findings and reveal that early or late maturation was neither an entirely positive or negative experience.

Others have examined various indices of pubertal change and found effects of puberty on feelings and emotions. For example, in boys, body image improved with perceived pubertal development (Tobin-Richards, Boxer, \& Petersen, 1983). Nottelmann and colleagues (1987c) found that pubertal stage in boys was the best predictor of social-emotional functioning one year later. Brooks-Gunn and Warren (1988) reported that in girls, the external pubertal changes evident to others were more likely to have an effect upon psychological functioning.

Among girls, pubertal change frequently was viewed negatively. For example, Dornbusch and colleagues (1984) reported that the normal body changes in girls during puberty are evaluated negatively by adolescent girls. Similarly, Zakin, Blyth, and Simmons (1984) reported that girls who were more attractive were more anxious about becoming pubertal than less attractive girls. Early maturing girls also were less satisfied with their weight than later maturing girls (Simmons, et al., 1983). Other findings (Tobin-Richards, Boxer, \& Petersen, 1983), showed that earlier maturing girls had less positive body image and feelings of attractiveness. On the other hand, Garwood and Allen (199) found that postmenarcheal girls reported more problems but had a better overall self-concept.

In the present study, the research questions focused on pubertal status and two aspects of the intrapersonal dimension that were hypothesized to be important during early adolescence; that is, satisfaction with appearance and moods. Although the effects of hormonal increases on these variables could not be tested directly, it was feasible to examine the effects of somatic development which include both underlying hormone effects and the effects of a more mature appearance. ${ }^{1}$ Two questions were posed:

\footnotetext{
${ }^{1}$ Note that examining pubertal status, a variable that changes for each individual over puberty, is distinctly different from examining pubertal timing, the relative timing of individual changes compared to peers. The latter variable is a constant and can be indexed by measuring, for example, age at peak growth. Given that pubertal status then is variable changing over time, it must be examined in "snapshots" or chronological slices. The longitudinal data were used to examine associations with pubertal status at each grade studied.
} 
(a) What are the effects of pubertal status upon satisfaction with appearance and mood states among adolescents; and (b) What are the patterns of those pubertal effects in sixth, seventh, and eighth grades?

\section{METHOD}

\section{Design}

The present research is part of a larger study of development in early adolescence: The Early Adolescence Study (Petersen, 1984). The study utilized a cohort-sequential longitudinal design (Baltes, 1968; Schaie, 1\%5) involving repeated measures with two cohorts of young adolescents. Participants were interviewed twice annually, in the fall and the spring of each school year, over a three-year period beginning in the sixth grade. Additionally the young adolescents participated in group testing sessions twice annually to complete paper and pencil measures assessing cognitive, psychological, and social development.

In Cohort 1, the adolescents sampled were members of the 1967-68 birth cohort and, in Cohort 2, the 1968-69 birth cohort. Adolescents were sampled randomly from two mid-west suburban school districts. They were primarily Caucasian and from middle to upper-middle class families (see Richardson, Galambos, Schulenberg \& Petersen, 1984, for further demographic information). In each cohort, adolescents showed little variation with respect to chronological age.

At the beginning of the sixth grade school year, students were selected randomly from class lists in the two schools. Letters and consent forms were sent to the students and their parents, describing the study and requesting participation. Those consenting were enrolled in the study. A consent rate of 80 percent was obtained with little variation by cohort or school district. Total sample size was 335 but data reported here were based on a subsample of 253 boys and girls who participated in at least four interviews and four group assessment sessions with the paper and pencil measures over the threeyear time period. The longitudinal sample of 253 does not appear to differ from the total sample on any measures examined to date.

\section{Measures}

Pubertal Development Scale (Petersen, Crockett, Richards, \& Boxer, 1988). Pubertal development was assessed using a brief self-report instrument developed as part of the larger study. This scale has been found to be both reliable and valid. In the interview, each adolescent was asked to report the amount of change or development noted in various physical characteristics of pubertal development. A four point scale $(1=$ no development to $4=$ development completed), was used to rate pubic hair growth, skin changes and the growth spurt in both boys and girls. Additionally, boys rated facial hair and voice deepening and girls rated breast development and menarcheal status. The sets of items form scales consisting of five items for each gender, coded on a fourlevel ordinal response scale. An overall pubertal development score was computed by summing across the five items to obtain a total score. The sum of the scores on the 
five indicators was divided by five to preserve the original $(1-4)$ metric. ${ }^{2}$ In addition, pubertal status scores were categorized into levels of development; $(1)=$ Pre-Pubertal, (2) = Beginning-Pubertal, (3) = Mid-Pubertal, (4) = Advanced-Pubertal, and (5) $=$ Post-Pubertal . Categorizations were based on the most reliable indicators for each gender. For girls, the categories were based on reported level of breast development, hair growth and menarcheal status. For boys, the categories were based on reported body hair growth, facial hair growth and voice changes. For the present analyses the pubertal status categories were used in order to treat pubertal status as an independent variable. Thus, each adolescent's pubertal development was categorized in the range of Pre-Pubertal to Post-Pubertal. The cell proportions for these categories by grade in school, time of interview, and gender appear in Table 1.

\section{TABLE 1}

Frequency Distributions of Boys and Girls across Pubertal Categories*

\begin{tabular}{lccccc}
\hline & \multicolumn{5}{c}{ Grade-Season } \\
\cline { 2 - 6 } Category & 6 & 7 & 7 & 8 & 8 \\
\hline Boys & Spring & Fall & Spring & Fall & Spring \\
$1=$ prepubertal & $17 \%$ & $11 \%$ & $11 \%$ & $3 \%$ & $2 \%$ \\
$2=$ early pubertal & $60 \%$ & $51 \%$ & $44 \%$ & $35 \%$ & $13 \%$ \\
$3=$ mid pubertal & $23 \%$ & $36 \%$ & $38 \%$ & $49 \%$ & $57 \%$ \\
$4=$ late pubertal & $0 \%$ & $2 \%$ & $7 \%$ & $13 \%$ & $27 \%$ \\
$5=$ post pubertal & $0 \%$ & $0 \%$ & $0 \%$ & $1 \%$ & $1 \%$ \\
$\quad \bar{X}(S D)$ & $2.06(.64)$ & $2.29(.69)$ & $2.41(.77)$ & $2.74(.75)$ & $3.12(.71)$ \\
Girls & & & & & \\
$1=$ prepubertal & $5 \%$ & $9 \%$ & $3 \%$ & $1 \%$ & $0 \%$ \\
$2=$ early pubertal & $16 \%$ & $7 \%$ & $5 \%$ & $2 \%$ & $0 \%$ \\
$3=$ mid pubertal & $58 \%$ & $60 \%$ & $54 \%$ & $35 \%$ & $25 \%$ \\
$4=$ late pubertal & $18 \%$ & $21 \%$ & $29 \%$ & $43 \%$ & $45 \%$ \\
$5=$ post pubertal & $4 \%$ & $3 \%$ & $9 \%$ & $19 \%$ & $30 \%$ \\
$\quad \bar{X}(S D)$ & $2.89(.83)$ & $3.03(.88)$ & $3.36(.83)$ & $3.76(.81)$ & $4.05(.74)$ \\
\hline
\end{tabular}

Note: Data for sixth-grade spring and seventh-grade fall are from Cohort II only $(n=113)$; otherwise, the two cohorts were pooled $(n=240)$.

* Since the original publication, the names have been changed to add clarification: $1=$ Pre-Pubertal; $2=B e$ ginning-Pubertal; 3 =Mid-Pubertal; $4=$ Advanced-Pubertal; and $5=$ Post-Pubertal. From Crockett, L.J., \& Petersen, A.C. (1987). Pubertal status and psychosocial development: Findings from the Early Adolescence Study. In R. M. Lerner \& T. T. Foch (Eds.), Biological-psychosocial interactions in early adolescence. Hillsdale, NJ: Lawrence Earlbaum Associates. Reprinted by permission.

${ }^{2}$ Further information on the Pubertal Development Scale (PDS), the scoring procedure, and a description of the categorization procedure, may be obtained by writing to the third author. 
Self-image Questionnaire for Young Adolescents (Petersen, Schulenberg, Abramowitz, Offer, \& Jarcho, 1984). In the Early Adolescent Study self-image was assessed using the Self-Image Questionnaire for Young Adolescents (SIQYA), a self-report measure developed from the Offer Self-image Questionnaire (Offer, Ostrov, \& Howard, 1982). The SIQYA is a 98 item questionnaire that assesses self-perceptions of functioning in nine domains: Impulse Control, Emotional Tone, Body-Image, Coping, Psychopathology, Superior Adjustment, Peer Relations, Family Relations, and Vocational and Educational Goals. Analyses for this study utilized a number of these subscales rather than "Self-Image" as a total score. Subscales were used as one component of the constructs measured; (e.g., the Body-Image subscale was a component of "Satisfaction with appearance").

Satisfaction with appearance. Multiple measures were used to assess satisfaction with appearance. From the semiannual interviews with the adolescent, questions were used concerning: (a) perception of one's attractiveness, (b) satisfaction with height, weight, and timing of pubertal development with respect to the peer group, (c) the desire to change one's physical appearance, and (d) the Body-Image subscale from the SIQYA.

Moods. To assess moods three of the SIQYA subscales were used: Impulse Control, Emotional Tone, and Psychopathology. In addition, two questions from the eighth grade interview were used: "How often do you have frequent mood changes that you cannot explain or control?"; and "How often do you get upset or angry?" Both interview items were coded on a five point scale ranging from very rarely to very often.

\section{RESULTS}

Multivariate analyses of variance were used to examine pubertal status effects within each grade level. Although the data are longitudinal, it is essential to hold something (i.e., grade) constant in order to address the questions. Analyses were done separately for boys and girls to alleviate the confounding of pubertal status effects with gender effects. Additionally in the analyses, separate polynomial contrasts were performed at each grade level to examine linear and quadratic trends across the pubertal status categories. For each grade level (sixth, seventh and eighth) pubertal status was defined as the independent variable. Dependent variables for these analyses were the multivariate constructs of Satisfaction with Appearance, and Moods. Not all interview questions were asked at each of the three grade levels. Therefore, some of the particular variables used to measure the constructs varied from one grade to the next. Table 2 shows the variables used at each time of measurement. There were no significant findings for sixth grade data.

\section{Satisfaction with Appearance}

Effects of pubertal status upon adolescent's satisfaction with appearance emerged for both boys and girls but only in seventh and eighth grade. The means by gender and pubertal status appear in Table 3. The multivariate effects were significant for girls in seventh grade, $F(12,338)=2.72, p=.002$, and eighth grade, $F(5,114)=3.14, p=$ .011 . Only one of the appearance variables, satisfaction with weight, showed a signif- 
TABLE 2

Variables Included in the Multivariate Construct by Grade Level

\begin{tabular}{|c|c|c|c|}
\hline & 6 th & 7 th & 8 th \\
\hline Satisfaction with & $\begin{array}{l}\text { Body Image } \\
\text { Desire to change } \\
\text { appearance }\end{array}$ & $\begin{array}{l}\text { Body Image } \\
\text { Desire to change } \\
\text { appearance } \\
\text { Satisfied with timing } \\
\text { of puberty } \\
\text { Satisfied with weight }\end{array}$ & $\begin{array}{l}\text { Body Image } \\
\text { Desire to change } \\
\text { appearance } \\
\text { Satisfied with timing } \\
\text { of puberty } \\
\text { Satisfied with weight } \\
\text { Satisfied with height }\end{array}$ \\
\hline Moods & $\begin{array}{l}\text { Impulse Control } \\
\text { Emotional Tone } \\
\text { Psychopathology }\end{array}$ & $\begin{array}{l}\text { Impulse Control } \\
\text { Emotional Tone } \\
\text { Psychopathology }\end{array}$ & $\begin{array}{l}\text { Impulse Control } \\
\text { Emotional Tone } \\
\text { Psychopathology } \\
\text { Frequency of getting } \\
\text { upset } \\
\text { Frequency of mood } \\
\text { swings }\end{array}$ \\
\hline
\end{tabular}

icant univariate effect for pubertal status in girls, $F(3,117)=7.53, p \leq .001$ in seventh grade; and $F(1,118)=12.24, p=.001$, in eighth grade. Figure 1a shows the means by gender and pubertal status for the significant univariate effect.

In seventh grade, there was a significant linear trend, $t=3.67, p \leq .001$, and a significant quadratic trend, $t=-3.27, p=.001$ indicating that girls who were more physically mature were generally less satisfied with their weight. The trend was reversed for PostPubertal girls who were slightly more satisfied with their weight than Advanced-Pubertal girls. In eighth grade, there also was a significant linear trend, $t=3.50, \mathrm{p}=.001$ for satisfaction with weight, generally indicating a replication of findings from seventh grade.

Multivariate effects for boys were not significant in seventh or eighth grade. In the seventh grade there was, however, a significant univariate effect, $F(3,95)=3.14, p=$ .029 , for satisfaction with weight. The quadratic trend was significant $t=2.35, p=.021$ showing that Mid-Pubertal boys had a slight decline in satisfaction with weight as compared with those earlier or later. (See Figure 1a.)

In eighth grade boys, the only significant univariate effect, $F(3,98)=3.33, p=$ .023 , was with wanting to change one's appearance. There was a significant quadratic trend, $t=2.73, p=.007$. As in the seventh grade, more physically mature boys reported less desire to change their appearance than did those less physically mature.

\section{Moods}

Significant pubertal status effects upon moods appeared only in the seventh and eighth grades. These effects were more consistent for boys than for girls. The only significant multivariate effect, $F(6,194)=2.55, p=.021$, emerged for seventh grade 
TABLE 3

Means and Standard Deviations ${ }^{a}$ by Sex and Pubertal Status for Variables with Significant Univariate Effects for the Multivariate Construct Satisfaction with Appearance and Moods

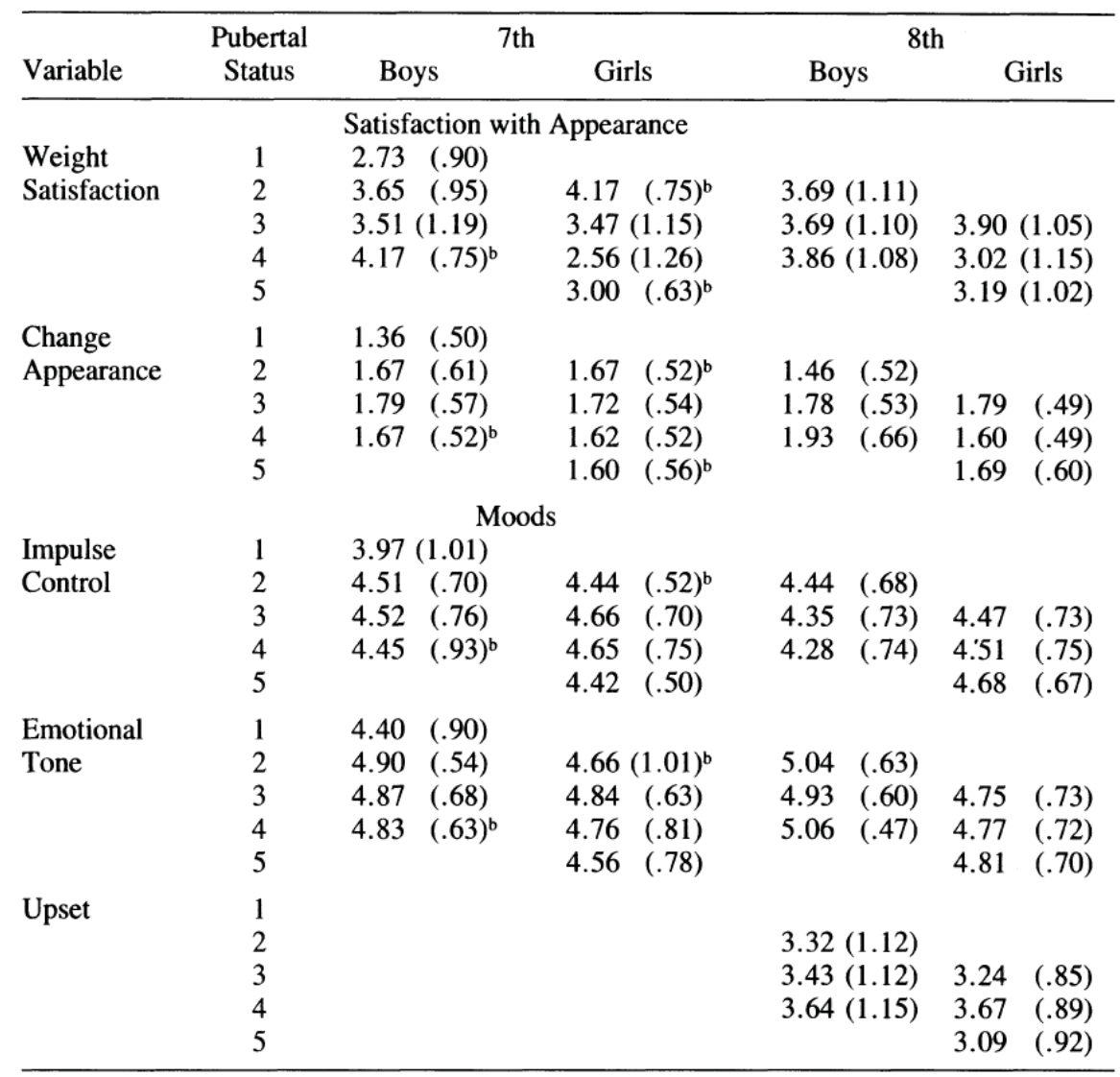

Note. There are no significant findings for sixth grade.

a: Standard deviations appear in parentheses

b: Cell size $=5-10$ subjects. Cells $<5$ are not represented

boys. The univariate effects were not significant although there was a significant linear trend for pubertal status on two subscales of the SIQYA; Impulse Control, $t=2.17$, $\mathrm{p}=.039$, and Emotional Tone, $\mathrm{t}=2.16, \mathrm{p}=.033$. A positive trend was noted in both variables such that group means were higher in all categories of the pubertal boys as compared with Pre-Pubertal boys. Thus, pubertal boys had better Impulse Control and Emotional Tone. Means for each variable for boys appear in Table 3 by pubertal status. Figure $1 \mathrm{~b}$ and $1 \mathrm{c}$ shows the pattern of means for the two variables. The figures show that the significant effects were clearly a function of the lower Impulse Control and Emotional Tone reported by Pre-Pubertal boys. Among pubescent boys, pubertal status 


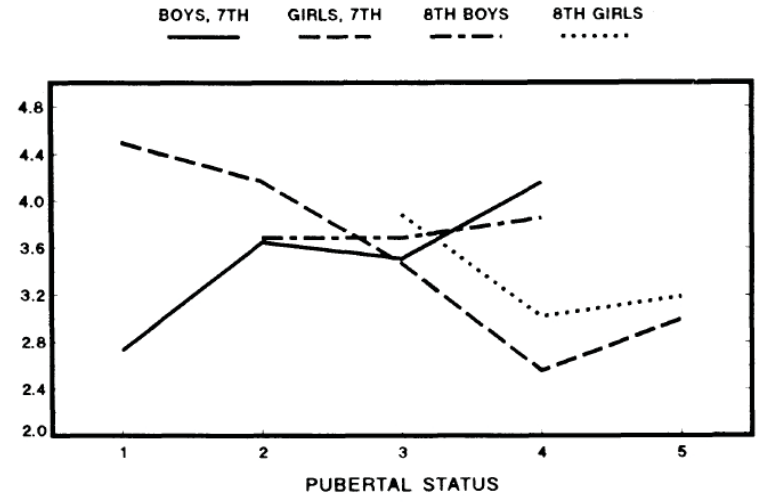

(a)

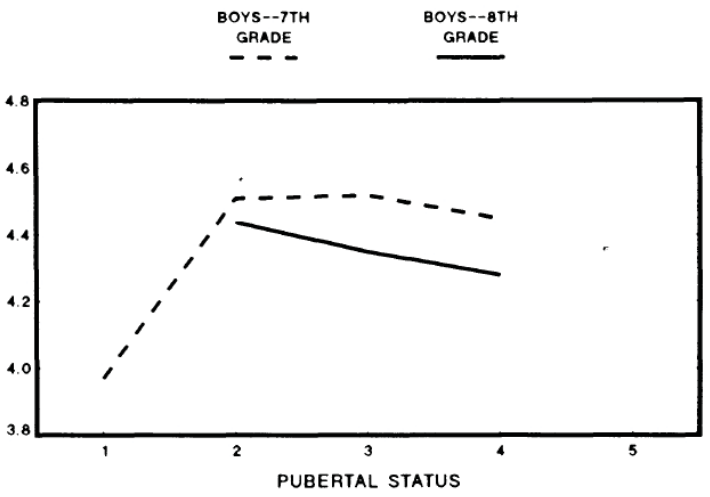

())

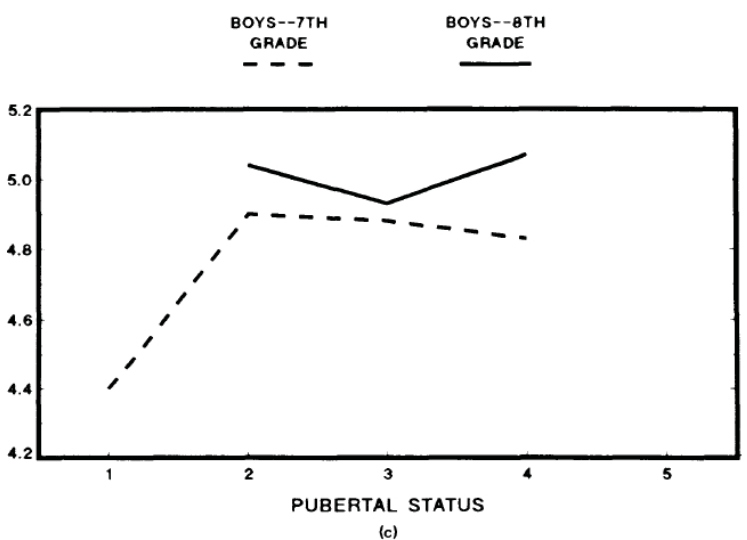

Figure 1. Mean rating for (a) Weight Satisfaction, (b) Impulse Control, and (c) Emotional Tone by pubertal status for seventh and eighth graders. 
did not appear to be associated with either mood variable. The effect was produced by the differences between prepubescent and pubescent boys, suggesting a threshold effect of puberty.

Neither multivariate nor univariate effects for eighth grade boys were significant. However, there was a significant linear trend for Emotional Tone, $t=2.17, p=.032$. The pattern of means was similar to that of seventh grade boys for both Impulse Control and Emotional Tone. This reinforces the notion of a threshold effect associated with being pubescent. In eighth grade, when there are no prepubescent boys (cell size is less than 5), there is no effect of increasing pubertal status as was true among pubescent boys in the seventh grade.

For eighth grade girls for moods, the multivariate effect was not significant. There was a significant univariate effect, $F(4,114)=4.37, p=.003$, on one variable, the reported frequency of becoming upset. A significant quadratic trend, $t=2.82, p=.006$, was evident in which Advanced-Pubertal girls reported a lesser tendency to become upset than either those less physically mature or more physically mature.

\section{DISCUSSION}

Pubertal changes have been ascribed an important role in various aspects of adolescent development. This paper focused on pubertal influences upon selected salient intrapersonal domains in the lives of young adolescents. More specifically, the interests were two-fold: first, to determine the effects of pubertal status upon satisfaction with appearance and moods; and second, to determine the patterns of those effects at different grade levels.

\section{Satisfaction with Appearance}

Findings suggest that pubertal status does influence the intrapersonal domains which were examined. Although there were no significant findings in sixth grade, significant multivariate effects were evident in the indicators of satisfaction with appearance in seventh and eighth grade girls but not in boys. Significant univariate findings were consistent in both seventh and eighth grades in that the salient aspect of appearance for girls was satisfaction with weight. Generally, in both grades, girls who were more physically mature reported being less satisfied with their weight. This finding is consistent with the trend of thinking in America where being thin as a female is a very desirable characteristic (Faust, 1983). It is likely these more physically mature females also weighed more. Because puberty in girls is accompanied by an increase in body fat and weight, more mature girls may feel less satisfied with their appearance. Studies of early maturing girls (e.g., Duncan, Ritter, Dornbusch, Gross, \& Carlsmith, 1985; Simmons et al., 1983) also have indicated that early maturing girls were more dissatisfied with their weight or wanted to be thinner than later maturers who had not yet experienced pubertal weight gain. Interestingly, other findings from the present sample suggest that an adolescent's actual weight may not be as important to Body-Image and Emotional Tone as their self-evaluation of physical dimensions (Sarigiani \& Dorn, 1986). 
The increase in satisfaction with weight among Post-Pubertal girls also was consistent with the pubertal weight gain hypothesis. In the early-and mid-stages of puberty, weight gain and fat deposition may not occur simultaneously with height increases. Thus, at these stages, girls may appear overweight because their weight is disproportionate to their height. At later stages of puberty, female fat deposition and body structures are more commensurate with height, which may lead to greater satisfaction with one's weight. This was precisely the pattern found among the eighth grade girls: Post-Pubertal girls were somewhat more satisfied with body weight than Advanced-Pubertal girls.

A univariate effect for satisfaction with weight also was significant for boys in seventh grade although the pattern was reversed from that of girls (see Figure la). More physically mature boys reported greater satisfaction with their weight. This finding is congruent with the timing literature which reported that early maturing boys were viewed more positively by adults and as more attractive by peers (Jones, 1965; Jones \& Bayley, 1950), as well as more relaxed and respected by peers (Blyth, et a]., 1981b). Boys who are more physically mature may be receiving reinforcement from others and thus, may view themselves more positively.

The desire to change one's appearance showed a significant univariate trend only among eighth grade boys. The multivariate effects were not significant. As boys' pubertal development increased, they were less likely to want to change their appearance. On the contrary, more mature girls in the seventh and eighth grades were more likely to want to change their appearance, although this effect did not reach significance. It appears that the link between satisfaction with appearance and pubertal status is complex, and that girls and boys may channel their feelings regarding this development in different ways. Boys may feel that being more developed may make them more successful in sports as well as more attractive to girls and popular with peers. For girls, the increase in weight associated with puberty and the ambivalent attitudes towards menarche (Ruble \& Brooks-Gunn, 1982) may make pubertal development less appealing.

\section{Moods}

Reporting of moods was the second indicator of the intrapersonal dimension used to examine pubertal effects. For boys, the multivariate effect was significant for moods in the seventh grade. Significant univariate effects or polynomial trends were scattered across both grade levels (seventh and eighth only) for two indicators of the intrapersonal dimension. Thus, pubertal status generally appears to influence rather specific aspects of these indicators rather than the multivariate construct as a whole. Of interest is the relatively consistent pattern for Impulse Control and Emotional Tone among seventh and eighth grade boys. Pubertal boys rated themselves higher on these two subscales; that is, their Impulse Control and Emotional Tone were better than that of Pre-pubertal boys. It appears that pubertal boys may be reacting positively to these changes. Caution is indicated, however, as the findings are based on cross-sectional analyses. Longitudinal analyses could show whether there truly is a change in Impulse Control and Emotional Tone as boys progress from prepubescence to pubescence. 
In the literature, moodiness is reported to be characteristic of the adolescent period of development, and hormones are often hypothesized to be the causal factor. To date, there is little empirical evidence to support or refute this. The self-report data presented here showed a significant multivariate effect for the moodiness variables for boys in the seventh grade: pubertal boys reported less moodiness as indicated by higher scores on Impulse Control and Emotional Tone.

The lack of findings in the sixth grade data may have resulted from less variability in pubertal status at the sixth grade, particularly among boys. Furthermore, the measure of pubertal status may have been directed more towards aspects of pubertal change which tend to occur later; if so, fewer adolescents in sixth grade would have been likely to report themselves as pubertal. There are hormone changes and more subtle external physical changes (e.g., increase in testicular volume) which often begin earlier. In addition, it is possible that effects of pubertal change are more salient in the junior high school context (i.e., at seventh and eighth grade) for most of this sample. That is, the move to the larger, more anonymous environment of the junior high school merely makes more salient those superficial, highly visible characteristics such as size and shape. It is also the case that pubertal variation is greatest at seventh grade making this a salient factor for comparison.

In general, the data support the notion that puberty is influential within the intrapersonal domain. Findings for satisfaction with appearance, particularly the pattern for weight satisfaction in girls, appears to replicate across grade level. The gender differences seen in these variables appear to be congruent with other literature and with what is observed in our culture today. These findings do not imply causal relations between puberty and the intrapersonal domains. Alternative explanations for changing feelings regarding satisfaction with appearance and moods cannot be ruled out and will make interesting questions for future research. With the complexity of this developmental period, it is encouraging that there are significant findings for pubertal status in this group of young adolescents. A multivariate approach studying the effects of puberty upon various pertinent domains would appear to hold promise for understanding this developmental period.

\section{REFERENCES}

Anisman, H., \& Lapierre, Y. D. (1982). Neurochemical aspects of stress and depression: Formulations and caveats. In R. W. J. Neufeld, (Eds.) Psychological stress and psychopathology. (pp. 179-217). New York: McGraw-Hill.

Baltes, P. B. (1968). Longitudinal and cross-sectional sequences in the study of age and generation effects. Human Development 11, 145-171.

Billy, J. 0. G., \& Udry, J. R. (1983). The effects of age and pubertal development on adolescent sexual behavior. Unpublished manuscript, Carolina Population Center, University of North Carolina at Chapel Hill.

Blos, P. (1962). On adolescence: A psychoanalytic interpretation New York: Free Press.

Blyth, D., Hill, J. P., \& Smith, C. K. (1981a). The influence of older adolescents on younger adolescents: Do grade level arrangements make a difference in behaviors, attitudes, and experience? Journal of Early Adolescence, 1, 85-110.

Blyth, D. A., Simmons, R G., Bulcroft, R., Felt, D., Van Cleave, E. F., \& Bush, D. M. (1981b). The ef- 
fects of physical development on self-esteem and satisfaction with body-image for early adolescent males. Research in Community Mental Health, 2, 43-73.

Blyth, D. A., Simmons, R. G., \& Zakin, D. F. (1985). Satisfaction with body image for early adolescent females: The impact of pubertal timing within different school environments. Journal of Youth and Adolescence, 14, 207-225.

Brooks-Gunn, J., \& Warren, M. (1987a, April). Biological contributions to affective expression in young adolescent girls. In E. J. Susman (Chair), Hormone status at puberty: Consequences for adolescents and their families Symposium conducted at the meeting of Society for Research in Child Development, Baltimore, MD.

Brooks-Gunn, J., \& Warren, M. (1988). The psychological significance of secondary sex characteristics in 9-to 11-year-old girls. Child Development, 59, 1061-1069.

Crockett, L. C., \& Petersen, A. C. (1987). Pubertal status and psychosocial development: Findings from the Early Adolescence Study. In R M. Lerner \& T. T. Foch (Eds.). Biological and psychosocial interactions in early adolescence, (pp. 173-188). Hillsdale, NJ: Erlbaum.

Dornbusch, S. M., Carlsmith, J. M., Duncan, P. D., Gross, R T., Martin, J. A., Ritter, P. C., \& SiegelGorelick, B. (1984). Sexual maturation, social class, and the desire to be thin among adolescent females. Developmental and Behavioral Pediatrics, 5, 308-314.

Duncan, P. D., Ritter, P. L., Dornbusch, S. M., Gross, R T., \& Carlsmith, J. M. (1985). The effects of pubertal timing on body image, school behavior, and deviance. Journal of Youth and Adolescence, $14,227-236$.

Faust, M. S. (1983). Alternative construction of adolescent growth. In J. Brooks-Gunn \& A. C. Petersen (Eds.), Girls at puberty: biological and psychosocial perspectives, (pp. 105-126). New York: Plenum.

Freud, A. (1958). Adolescence. In R. S. Eissler, (Ed.), Psychoanalytic study of the child, (Vol. 13), (pp. 255-278). New York: Plenum.

Freud, S. (1953). A general introduction to psychoanalysis (Joan Riviere, trans.). New York: Permabooks (originally published, 1905).

Garwood, S. G., \& Allen, L. (1979). Self-concept and identified problem differences between pre-and postmenarcheal adolescents. Journal of Clinical Psychology, 35, 528-537.

Gold, P. W., Gwirtsman, H., Averginos, P. C., Nieman, L., Gallucci, W. T., Kaye, W., Jimerson, D., Ebert, M., Rittmaster, R. W., Loriaux, D. L., \& Chrousos, G. P. (1986a). Abnormal hypothalamic-pituitary-adrenal function in anorexia nervosa. New England Journal of Medicine, 314, 1335-1342.

Gold, P. W., Loriaux, D. L., Roy, A., Kling, M. A., Calabrese, J. R, Kellner, C. H., Post, R. M., Pickar, D., Gallucci, W., Averginos, P. C., Paul, S., Oldfield, E. H., Cutler, G. B., Jr., \& Chrousos, G. P. (1986b). Abnormal hypothalamic-pituitary-adrenal function in anorexia nervosa: Pathophysiologic mechanisms in underweight and weight-corrected patients. New England Journal of Medicine, 314, 1329-1334.

Hall, G. S. (1904). Adolescence: Its psychology and its relations to psychology, anthropology, sociology, sex, crime, religion, and education New York: Appelton.

Hamburg, B. A. (1974). Early adolescence: A specific and stressful stage of the life cycle. In G. Coelho, D. A. Hamburg, \& J. E. Adams (Eds.), Coping and adaptation (pp. 101-124). New York: Basic Books.

Hill, J., Holmbeck, G., Marlow, L., Green, T. M., \& Lynch, M. E. (1985). Menarcheal status and parent-child relations in families of seventh-grade girls. Journal of Youth and Adolescence, 14, 301-316.

Inoff-Germain, G., Arnold, G. S., Susman, E. J., Nottelmann, E. D., Cutler, G. B. Jr., \& Chrousos, G. P. (1988). Relations between hormone levels and observational measures of aggressive behavior of young adolescents in family interactions. Developmental Psychology, 24, 129-139.

Jones, M. C. (1965). Psychological correlates of somatic development. Child Development, 36, 899-911. 
Jones, M. C., \& Bayley, N. (1950). Physical maturing among boys as related to behavior. Journal of Educational Psychology, 41, 129-148.

Jones, M. C., \& Mussen, P. H. (1958). Self-conceptions, motivations, and interpersonal attitudes of early-and late-maturing girls. Child Development, 29, 491-501.

Kestenberg, J. (1\%7a). Phases of adolescence with suggestions for a correlation of psychic and hormonal organizations: Antecedents of adolescent organizations in childhood, Part I, Journal of the American Academy of Child Psychiatry, 6, 427-463.

Kestenberg, J. (1\%7b). Phases of adolescence with suggestions for a correlation of psychic and hormonal organizations in childhood. Part 11, Journal of the American Academy of Child Psychiatry, 6, 577-614.

Kestenberg, J. (1968). Phases of adolescence with suggestions for a correlation of psychic and hormonal organizations in childhood. Part 111: Puberty, growth, differentiation, and consolidation. Journal of the American Academy of Child Psychiatry, 7 108-151.

Moms, N. M., Mallin, K, \& Udry, J. R. (1982, November). Pubertal development and current sexual intercourse among teens Paper presented at the annual meeting of the American Public Health Association, Montreal, Canada.

Nottelmann, E. D., Susman, E. J., Dorn, L. D., Inoff-Germain, G., Loriaux, D. L., Cutler, G. B., Jr., \& Chrousos, G. P. (1987a). Developmental processes in early adolescence: Relations among chronologic age, pubertal stage, height, weight, and serum levels of gonadotropins, sex steroids, and adrenal androgens. Journal of Adolescent Health Care, 8, 246-260.

Nottelmann, E. D., Susman, E. J., Inoff-Germain, G., Cutler, G., Loriaux, D. L., \& Chrousos, G. P. (1987b). Developmental processes in early adolescence: Relations between adolescent adjustment problems and chronological age, pubertal stage, and puberty-related serum hormone levels. Journal of Pediatrics, 110, 473-480.

Nottelmann, E. D., Susman, E. J., Inoff-Germain, G., \& Chrousos, G. P. (1987c, April). Concurrent and predictive relations between hormone levels and social-emotional functioning in early adolescence. In E. J. Susman (Chair), Hormone status at puberty: Consequences for adolescents and their families Symposium conducted at the meeting of the Society for Research in Child Development, Baltimore MD.

Nottelmann, E. D., Susman, E. J., Inoff-Germain, G., \& Chrousos, G. P., (in press). Hormones and behavior at puberty. In J. Bancroft (Ed.), Adolescence and puberty, London: Oxford University Press.

Nyborg, H. (1983). Spatial ability in men and women: review and new theory. Advances in Behavioral Research and Theory, 5, 89-140.

Offer, D., Ostrov, E., \& Howard, K. I. (1982). The Offer Self-Image Questionnaire for Adolescents: A manual (3rd ed.). Michael Reese Hospital, Chicago, IL.

Olweus, D., Mattsson, A, Schalling, D., \& Low, H. (1980). Testosterone, aggression, physical and personality dimensions in normal adolescent males. Psychosomatic Medicine, 42, 253-269.

Papini, D. R, \& Sebby, R A. (1987). Adolescent pubertal status and affective family relationships: A multivariate assessment. Journal of Youth and Adolescence, 16, 1-15.

Papini, D. R., \& Sebby, R. A. (1988). Variations in conflictual family issues by adolescent pubertal status, gender, and family member. Journal of Early Adolescence, 8, 1-16.

Parker, L. N., Levin, E. R., \& Lifrak, E. T. (1985). Evidence for adrenocortical adaptation to severe illness. Journal of Clinical Endocrinology and Metabolism, 60, 947-962.

Petersen, A. C., (1984). The early adolescence study. Journal of Early Adolescence, 4, 103-181.

Petersen, A. C. (1987). The nature of biological-psychological interactions: The sample case of early adolescence. In R M. Lerner \& T. T. Foch (Eds.). Biological and psychosocial interactions in early adolescence, (pp. 35-61). Hillsdale, NJ: Erlbaum.

Petersen, A. C., \& Crockett, L. J. (1985). Pubertal timing and grade effects on adjustment. Journal of Youth and Adolescence, 14, 191-206. 
Petersen, A. C., Crockett, L. J., Richards, M. H., \& Boxer, A. M. (1988). Measuring pubertal status: Reliability and validity of a self-report measure. Journal of Youth and Adolescence, 7: 117-133.

Petersen, A. C., Schulenberg, J., Abramowitz, R H., Offer, D., \& Jarcho, H. D. (1984). A self-image questionnaire for young adolescents (SIQYA): Reliability and validity studies. Journal of Youth and Adolescence, 13, 93-111.

Petersen, A. C. \& Spiga, R. (1982). Adolescence and stress. In L. Goldberger \& S. Breznitz (Eds.), Handbook of stress: Theoretical and clinical aspects, (pp. 515-528). New York: Macmillan.

Petersen, A. C., \& Taylor, B. (1980). The biological approach to adolescence. In J. Adelson, (Ed.), Handbook of adolescent psychology, (pp. 115-155). New York: Wiley.

Richardson, R, Galambos, N., Schulenberg, J., \& Petersen, A. C., (1984). Young adolescents' perceptions of the family environment. Journal of Early Adolescence, 4, 131-153.

Rose, R. M. (1980). Endocrine responses to stressful psychological events. Advances in psychoneuroendocrinology. Psychiatric Clinics of North America. 3, 251-276.

Ruble, D. N. \& Brooks-Gunn, J. (1982). The experience of menarche. Child Development, 53, 1557-1566.

Sarigiani, P. S., \& Dorn, L. D. (1986, March). The relationship between emotional tone and body image in early adolescence. Poster presented at the meeting of the Society for Research on Adolescence, Madison, WI.

Schaie, K. W. (1965). A general model for the study of developmental problems. Psychological Bulletin, 64, 92-107.

Simmons, R G., Blyth, D. A., \& McKinney, K. L. (1983). The social and psychological effects of puberty on white females. In J. Brooks-Gunn \& A. C. Petersen, (Eds.), Girls at puberty: Biological and psychosocial perspectives, (pp. 229-272). New York: Plenum.

Steinberg, L. D. (1987). Impact of puberty on family relations: Effect of pubertal status and pubertal timing. Developmental Psychology, 23, 451-460.

Steinberg, L. D., \& Hill, J. P. (1978). Patterns of family interaction as a function of age, the onset of puberty, and formal thinking. Developmental Psychology, 14, 683-684.

Susman, E. J., Inoff-Germain, G., Nottelmann, E. D., Loriaux, D. L., Cutler, G. B. Jr., \& Chrousos, G. P. (1987a). Hormones, emotional dispositions, and aggressive attributes in young adolescents. Child Development, 58, 1114-1134.

Susman, E. J., Nottelmann, E. D., Inoff-Germain, G., Dorn, L. D., \& Chrousos, G. P. (1987b). Hormonal influences on aspects of psychological development during adolescence. Journal of Adolescent Health Care, 8, 492-504.

Susman, E. J., Nottelmann, E. D., Inoff-Germain, G., Dorn, L. D., Cutler, G. B., Jr., Loriaux, D. L., \& Chrousos, G. P. (1985). The relation of relative hormonal levels and physical development and social-emotional behavior in young adolescents. Journal of Youth and Adolescence, 14, 245-264.

Tanner, J. M. (1\%2). Growth at adolescence Springfield, IL: Thomas.

Tobin-Richards, M. H., Boxer, A. M., \& Petersen, A. C. (1983). The psychological significance of pubertal change: Sex differences in perceptions of self during early adolescence. In J. Brooks-Gunn \& A. C. Petersen (Eds.), Girls at puberty: Biological and psychosocial perspectives, (pp. 127154). New York: Plenum.

Tolis, G., \& Stefanis, C. (1983). Depression: Biological and neuroendocrine aspects. Biomedicine and Pharmacotherapy, 33 316-322.

Zakin, D. F., Blyth, D. A., \& Simmons, R. G., (1984). Physical attractiveness as a mediator of the impact of early pubertal changes for girls. Journal of Youth and Adolescence, 13, 439-450. 